\title{
Storage and Viability of Entomopathgogenic fungus on agricultural and industrial waste
}

\author{
Rishi Pal ${ }^{1}$ and Rajendra Singh ${ }^{2 *}$ \\ ${ }^{1}$ Bio-Control Lab and ${ }^{2}$ Deptt. of Entomology \\ Sardar Vallabhbhai Patel University of Agriculture \& Technology, Meerut (UP), INDIA *Corresponding \\ author: singhrajendra0113@gmail.com
}

\begin{abstract}
A study conducted on storage and viability of Entomopathgogenic fungus, Beauveria bassiana, Metarhizium anisopliae and Verticillium lecanii in the laboratory by using liquid and solid agricultural and industrial waste media. FYM liquid + Press mud liquid $(1: 1)+1 \mathrm{~g}$ Dextrose $\left(43.62 \times 10^{7}\right.$ spores $\left./ \mathrm{ml}\right)$ followed by FYM $(37.25 \mathrm{X}$ $10^{7}$ spores $\left./ \mathrm{ml}\right)$ and Press mud $\left(29.75 \times 10^{7}\right.$ spores $\left./ \mathrm{ml}\right)$ were the most suitable substrate with higher production of spores and viability of B. bassiana at 6 month of storage period. However, The FYM $\left(25.37 \mathrm{X} 10^{7}\right.$ spores $\left./ \mathrm{ml}\right)$ produced maximum spores of $M$. anisopliae followed by FYM liquid + Press mud liquid (1:1) + $1 \mathrm{~g}$ Dextrose (23.57 $\mathrm{X} 10^{7}$ spores $\left./ \mathrm{ml}\right)$ and Jowar grain $+1.0 \mathrm{~g}$ Dextrose $\left(8.5 \times 10^{7}\right.$ spores $\left./ \mathrm{ml}\right)$ were the most suitable medium for spore production, viability and storage of $M$. anisopliae. While in case of $V$. lecanii, FYM $\left(23.8 \times 10^{7} \mathrm{spores} / \mathrm{ml}\right)$, followed by FYM liquid + $1 \mathrm{~g}$ Dextrose $\left(11.5 \times 10^{7}\right.$ spores $\left./ \mathrm{ml}\right)$ and Sabouraud dextrose broth $\left(4.75 \mathrm{X} 10^{7}\right.$ spores $\left./ \mathrm{ml}\right)$ were the most suitable media with higher growth of mycelium and production of large number of spores with viability of $V$. lecanii. However, sugarcane bugasse and crushed maize (Corcyra rearing waste) substrate were recorded no fungal spores. FYM was the best and suitable substrate for long time storage with viability of fungal spores.
\end{abstract}

Keyword: Storage, Viability of Entomopathgogenic, Fungus, Agrowaste

Paper Cited: Pal, R. and Singh, R. (2016). Storage and Viability of Entomopathgogenic fungus on agricultural and industrial waste. South Asian Journal of Food Technology and Environment, 2(1): 338343.

Received: 21/02/2016 Revised: 19/03/2016 Accepted: 27/03/2016

\section{Introduction}

The indiscriminate use of insecticides over the years has not only to control crop pest besides, it is one of the main causes for secondary pest out breaks in many crop ecosystem, pesticide resistance, more stringent pesticide regulation and concern about human health, environmental quality and adverse effects on non-target organisms also. In view of these side effects, the necessity for sustainable crop production through eco-friendly pest management technique is being largely felt in the recent times. Biological control agents such as entomopathogenic fungi (EPF) can be used as a component of integrated pest management (IPM) of many insect pests. Under natural conditions, these pathogens are a frequent and often cause natural mortalities of insect populations. The main drivers behind the push for myco-insecticides are the need for more specific agents as components of IPM programmes due to concerns over chemical residues on human health and the environment.

An attractive feature of these fungi is that infectivity is by contact and the action is through penetration (Nadeau et al., 1996). These fungi comprise a heterogenous group of over 100 genera with approximately 750 species, reported from different insects. Many of these offer a great potential in pest management. The most important fungal pathogens are Metarhizium spp., Beauveria spp., Nomuraea rileyi, Verticillium lecanii and Hirsutella spp. Of the over 750 species of fungi known to be pathogenic to insects, six have been commercialized and the cosmopolitan pathogens, such as B. bassiana, M. anisopliae are the best known so far. Fungi often cause spectacular epizootics with large number of pathogenic insects showing visible fungal outgrowth (Hall, 1982). Conservation and periodic enhancement of efficacy of biological 
control agents will help in crop protection and in producing agricultural commodities free from pesticide residues.

The major issues involved in mass production and utilization of mycopathogens are selection of effective strains, development of cost effective methods for mass rearing, development of effective methods for storage and shipment and creation of effective formulation. In this study we have evaluated different types of cultivation methods with different liquid and solid substrate for storage of different entomopathogenic fungi. It is therefore essential to determine the best substrate for spore production and their viability.

\section{Materials and Methods}

The present study was carried out in Bio-control Laboratory, S.V.P. University of Agriculture \& Technology, Meerut (India) in 2010. The experiment was conducted in laboratory to test the storage period for viability of entomopathogenic fungi on different agricultural and industrial waste (solid and liquid substrates).

Substrates and in vitro production: Nine mass production substrates were evaluated for the conidial production of $B$. bassiana, $M$. anisopliae and $V$. lecanii under temperature for period of six month. The substrates were (i) FYM, (ii) Sabouraud dextrose broth (SDB), (iii) Sugar industry Press mud, (iv) Sugarcane bagasse, (v) FYM liquid + 1.0g Dextrose, (vi) Pressmud liquid $+1.0 \mathrm{~g}$ Dextrose, (vii) FYM liquid + Pressmud liquid $(1: 1)+1.0 \mathrm{~g}$ Dextrose , (viii) Corcyra rearing waste (Maize) and (ix) Jowar grain $+1.0 \mathrm{~g}$ Dextrose. The last six medium were supplemented with dextrose. There were nine treatments in three replications.

A quantity of $130 \mathrm{~g}$ dehydrated SDB was suspended in $2000 \mathrm{ml}$ distilled water, heated to dissolve the medium ( $\mathrm{pH}$ 5.6) and sterilized by autoclaving at $15 \mathrm{lbs}$ pressure $\left(121^{\circ} \mathrm{C}\right)$ for 15 minutes. The lukewarm liquid media was poured in conical flask. Then B. bassiana,M. anisopliae and $V$. lecanii were inoculated aseptically and then conical flasks were incubated in BOD.
The Corcyra rearing waste (crushed maize grain) and sorghum grain were soaked overnight, cleaned with fresh water and $100 \mathrm{~g}$ of each was put in separate conical flasks $(250-\mathrm{ml}$ capacity) supplemented with dextrose $(1.0 \mathrm{~g})$, plugged with non-absorbent cotton and autoclaved. Upon cooling of media, B. bassiana, $M$. anisopliae and $V$. lecanii were inoculated aseptically and incubated in BOD incubator. The crushed jowar grain was collected from the Biocontrol Laboratory as a waste material from Corcyra Rearing Unit. The crushed jowar grain (weight $50 \mathrm{~g}$ ) was put in flask and $15 \mathrm{ml}$ distilled water with $1 \mathrm{~g}$ dextrose was added. The sugarcane bagasse and Pressmud was procured from Modipuram, Meerut. The sugarcane bagasse was cut into small pieces and half-filled in flask with $15 \mathrm{ml}$ distilled water.

Spore counting: A drop of conidial suspension of $B$. bassiana, $M$. anisopliae and $V$. lecanii (obtained from the growing media by filtering through muslin cloth) was placed on the hemocytometer. The cover glass was put over the grid carefully so that no air bubble entered between cover glass and slide. The conidia of entomopathogenic fungi were counted under Olympus BX41 phase contrast microscope at higher resolution in the middle square (V) of hemocytometer which contained 25 groups of 16 small squares, each group $0.2 \mathrm{~mm}$ square. This process was repeated every month for six times.

Statistical analysis: The conidial production of entomopathogernic fungi from different substrates were subjected to analysis of variance (ANOVA) using SPSS 10.0 for Windows software (SPSS, 1999). The means were separated using LSD and differences between treatments were considered significant at $p<$ 0.05 .

\section{Results and discussion}

Beauveria bassiana: Study on the viability of spores of $B$. bassiana at 6 month storage period on different agricultural and industrial waste(Table: 1). The results showed that the, $\left(\mathrm{T}_{7}\right)$ FYM liquid + Press mud liquid $(1: 1)+1 \mathrm{~g}$ Dextrose $\left(43.62 \times 10^{7}\right.$ spores $\left./ \mathrm{ml}\right)$ followed by $\left(\mathrm{T}_{1}\right)$ FYM (37.25 X $10^{7}$ spores $\left./ \mathrm{ml}\right)$ and $\left(\mathrm{T}_{3}\right)$ Press 
mud $\left(29.75 \times 10^{7}\right.$ spores $\left./ \mathrm{ml}\right)$ and $\left(\mathrm{T}_{6}\right)$ pressmud liquid +1 gram Dextrose $\left(23.62 \times 10^{7}\right.$ spores $/ \mathrm{ml}$ ) were the most suitable substrate with higher production of spores and viability at 6 month of storage period of $B$. bassiana. Treatment $\left(\mathrm{T}_{2}\right) \mathrm{SDB},\left(\mathrm{T}_{4}\right)$ sugarcane bugasse and $\left(\mathrm{T}_{9}\right)$ Jowar grain $+1.0 \mathrm{~g}$ Dextrose substrate have no fungal spores were recorded at the storage period of six month. These findings are in agreement with the findings of Nelson et al., (1996) who found that for spore production of $B$. bassiana and Metarhizium, these fungi produced more spores on rice over other growing substrates. Pandey and Kanaujia (2008) found that the conidial production of EPFs is affected by the type of growing medium. This was also in agreement with Ibrahim and Low (1993) and Sharma et al., (2002) who found rice to be the suitable media for the mass culture of $B$. bassiana and the cereal was also suitable for the mass production of other deuteromycete fungi. The substrates used in this experiment were relatively cheap, easily available and acted as nutritive media for mass production of the EPFs.

Metarhizium: The results showed that (Table 2) significant different among the media tested,
$\left(\mathrm{T}_{5}\right)$ FYM $\left(25.37 \times 10^{7}\right.$ spores $\left./ \mathrm{ml}\right)$ followed by $\left(\mathrm{T}_{7}\right) \mathrm{FYM}$ liquid + Press mud liquid $(1: 1)+1 \mathrm{~g}$ Dextrose $\left(23.57 \times 10^{7}\right.$ spores $\left./ \mathrm{ml}\right)$ and $\left(\mathrm{T}_{9}\right)$ and Jowar grain $+1.0 \mathrm{~g}$ Dextrose $\left(8.5 \times 10^{7}\right.$ spores $/ \mathrm{ml}$ ) were the most suitable medium for spore production, viability and storage of $M$. anisopliae. However, treatment $\left(\mathrm{T}_{2}\right) \mathrm{SDB},\left(\mathrm{T}_{4}\right)$ sugarcane bugasse and $\left(\mathrm{T}_{8}\right)$ Corcyra rearing waste (crushed maize) substrate have no fungal spores were recorded at the period of six month of storage. The high amount of conidia in bajra and rice could be due to maltose released by the action of starch hydrolyzing enzymes present in the fungus inducing sporulation. Pressmud +10 per cent molasses supported least yield $0.42 \mathrm{x}$ $10^{4}$ spore/ g, where initiation of growth and sporulation resulted only after 20 days after inoculation (Bharati et al., 2007). Nelson et al., (1996) found that spore production of $B$. bassiana and Metarhizium, these fungi produced more spores on rice over other growing substrates. Pandey and Kanaujia (2008) found that the conidial production of EPFs is affected by the type of growing medium. The substrates used in this experiment were relatively cheap, easily available and acted as nutritive media for mass production of the EPFs.

Table 1: Viability of Entomopathogenic fungi, $B$. bassiana on the different agricultural and industrial waste

\begin{tabular}{|c|c|c|c|c|c|c|c|c|c|}
\hline $\begin{array}{c}\text { Viability } \\
\text { periods } \\
\text { (Months) }\end{array}$ & \multicolumn{7}{|c|}{ Treatments } \\
\cline { 2 - 10 } & $\mathbf{T}_{\mathbf{1}}$ & $\mathbf{T}_{\mathbf{2}}$ & $\mathbf{T}_{\mathbf{3}}$ & $\mathbf{T}_{\mathbf{4}}$ & $\mathbf{T}_{\mathbf{5}}$ & $\mathbf{T}_{\mathbf{6}}$ & $\mathbf{T}_{\mathbf{7}}$ & $\mathbf{T}_{\mathbf{8}}$ & $\mathbf{T}_{\mathbf{9}}$ \\
\hline $\mathbf{1}^{\text {st }}$ & 27.87 & 24.62 & 11.40 & 6.52 & 9.75 & 13.25 & 20.00 & 11.97 & 13.52 \\
\hline $\mathbf{2}^{\text {nd }}$ & 29.21 & 26.46 & 13.84 & 4.62 & 10.06 & 15.75 & 23.81 & 11.08 & 8.31 \\
\hline $\mathbf{3}^{\text {rd }}$ & 30.48 & 18.71 & 19.95 & 1.83 & 11.73 & 18.81 & 28.75 & 12.00 & 6.88 \\
\hline $\mathbf{4}^{\text {th }}$ & 33.58 & 14.62 & 23.41 & 0.00 & 12.88 & 19.03 & 35.43 & 10.88 & 5.97 \\
\hline $\mathbf{5}^{\text {th }}$ & 36.27 & 6.81 & 26.28 & 0.00 & 13.24 & 22.00 & 38.68 & 10.76 & 5.01 \\
\hline $\mathbf{6}^{\text {th }}$ & 37.25 & 0.00 & 29.75 & 0.00 & 12.62 & 23.62 & 43.62 & 10.50 & 0.00 \\
\hline $\mathbf{C D}>5 \%$ & 6.041 & 4.395 & 6.021 & 1.749 & N.S. & 2.801 & 2.783 & NS & 1.820 \\
$\mathbf{S E ~}_{\mathbf{( m )}}$ & 1.939 & 1.411 & 1.933 & 0.561 & 0.849 & 0.899 & 0.893 & 0.944 & 0.584 \\
\hline
\end{tabular}

* mean of three replications 
V. lecanni: The results showed that significant difference among the media tested for viability (Table 3) of entomopathogenic fungi $V$. lecanii, $\mathrm{T}_{1}$ or FYM $\left(23.8 \times 10^{7}\right.$ spores $\left./ \mathrm{ml}\right)$, followed by $\left(\mathrm{T}_{5}\right)$ FYM liquid $+1 \mathrm{~g}$ Dextrose $(11.5 \times$ $10^{7}$ spores $\left./ \mathrm{ml}\right)$ and $\left(\mathrm{T}_{2}\right)$ Sabouraud dextrose broth $\left(4.75 \times 10^{7}\right.$ spores $\left./ \mathrm{ml}\right)$ were the most suitable media with higher growth of mycelium and production of large number of spores with viability of $V$. lecanii. While the treatment $\left(\mathrm{T}_{4}\right)$ sugarcane bugasse had no spores followed by $\left(\mathrm{T}_{6}\right)$ Press mud liquid $+1 \mathrm{~g}$ Dextrose and $\left(\mathrm{T}_{7}\right)$ FYM liquid + Press mud liquid $(1: 1)+1 \mathrm{~g}$ Dextrose at the six month of storage. The above finding indicated that the FYM was the best and suitable substrate for long time storage with viability of fungal spores.

Table 2: Viability of Entomopathogenic fungi, $M$. anisopliae on the different agricultural and industrial waste

\begin{tabular}{|c|c|c|c|c|c|c|c|c|c|}
\hline \multirow{2}{*}{$\begin{array}{l}\text { Viability } \\
\text { periods } \\
\text { (Months) }\end{array}$} & \multicolumn{9}{|c|}{ Treatments } \\
\hline & $\mathbf{T}_{1}$ & $\mathbf{T}_{2}$ & $\mathbf{T}_{3}$ & $\mathbf{T}_{4}$ & $\mathbf{T}_{5}$ & $\mathbf{T}_{6}$ & $\mathbf{T}_{7}$ & $\mathbf{T}_{8}$ & $\mathbf{T}_{9}$ \\
\hline $1^{\text {st }}$ & 17.17 & 15.72 & 4.57 & 3.42 & 5.55 & 6.35 & 8.32 & 7.87 & 5.70 \\
\hline $2^{\text {nd }}$ & 16.58 & 12.26 & 4.62 & 2.63 & 10.81 & 7.12 & 10.33 & 8.61 & 6.08 \\
\hline $3^{\text {rd }}$ & 11.37 & 7.19 & 4.67 & 1.88 & 13.06 & 8.34 & 14.67 & 6.77 & 6.91 \\
\hline $4^{\text {th }}$ & 8.05 & 5.08 & 4.84 & 0.86 & 18.51 & 6.67 & 19.33 & 3.63 & 7.43 \\
\hline $5^{\text {th }}$ & 6.87 & 2.16 & 4.99 & 0.00 & 21.73 & 5.33 & 21.81 & 1.02 & 8.00 \\
\hline $6^{\text {th }}$ & 4.52 & 0.00 & 5.33 & 0.00 & 25.37 & 4.70 & 23.57 & 0.00 & 8.50 \\
\hline CD > & 2.097 & 1.821 & N.S. & 0.510 & 1.557 & 1.530 & 2.325 & 1.258 & 1.304 \\
\hline SE (m) & 0.673 & 0.584 & 0.626 & 0.164 & 0.500 & 0.491 & 0.746 & 0.404 & 0.419 \\
\hline
\end{tabular}

* mean of three replications

Lakshmi et al., (2001) studied the mass culturing of $V$. lecanii on three grain media found that broken sorghum grain with a spore load $1.5 \times 10^{9}$ spores $^{-1}$ was the best followed by pearl millet broken grain medium with $1.3 \times 10^{9}$ spores $^{-1}$. Pandey and Kanaujia (2008) found that the conidial production of EPFs is affected by the type of growing medium. Derakshan et al., (2008) recorded spore count of $V$. lecanii on rice, sorghum and corn were on par and significantly higher than rangi and wheat. It was found that viable spore's counts in different grains are not significantly different. According to Moore et al. (2000), fungal spores are living organisms and their viability diminishes with time depending on environmental conditions, in this case the storage temperature. 
Table 3: Viability of Entomopathogenic fungi, $V$. lecanii on the different agricultural and industrial waste

\begin{tabular}{|c|c|c|c|c|c|c|c|c|c|}
\hline \multirow{2}{*}{$\begin{array}{l}\text { Viability } \\
\text { periods } \\
(\text { Months) }\end{array}$} & \multicolumn{7}{|c|}{ Treatments } \\
\cline { 2 - 10 } & $\mathbf{T}_{\mathbf{1}}$ & $\mathbf{T}_{\mathbf{2}}$ & $\mathbf{T}_{\mathbf{3}}$ & $\mathbf{T}_{\mathbf{4}}$ & $\mathbf{T}_{\mathbf{5}}$ & $\mathbf{T}_{\mathbf{6}}$ & $\mathbf{T}_{\mathbf{7}}$ & $\mathbf{T}_{\mathbf{8}}$ & $\mathbf{T}_{\mathbf{9}}$ \\
\hline $\mathbf{1}^{\text {st }}$ & 18.50 & 18.00 & 4.75 & 3.90 & 5.65 & 8.05 & 11.75 & 11.07 & 4.95 \\
\hline $\mathbf{2}^{\text {nd }}$ & 17.79 & 13.41 & 5.08 & 2.58 & 6.03 & 6.05 & 8.26 & 8.33 & 5.08 \\
\hline $\mathbf{3}^{\text {rd }}$ & 20.58 & 11.36 & 6.00 & 1.06 & 7.84 & 4.83 & 6.81 & 3.67 & 5.61 \\
\hline $\mathbf{4}^{\text {th }}$ & 21.06 & 6.59 & 6.16 & 0.61 & 8.93 & 3.61 & 5.76 & 2.33 & 4.08 \\
\hline $\mathbf{5}^{\text {th }}$ & 22.48 & 5.44 & 4.02 & 0.00 & 9.07 & 1.03 & 4.22 & 1.67 & 3.66 \\
\hline $\mathbf{6}^{\text {th }}$ & 23.80 & 4.75 & 3.70 & 0.00 & 11.50 & 0.00 & 3.62 & 0.00 & 3.25 \\
\hline $\mathbf{C D}>0.05 \%$ & 1.885 & 1.416 & 1.232 & 0.866 & 1.764 & 0.827 & 1.093 & 1.097 & 1.391 \\
$\mathbf{S E}(\mathbf{m})$ & 0.605 & 0.454 & 0.396 & 0.278 & 0.566 & 0.265 & 0.351 & 0.352 & 0.447 \\
\hline
\end{tabular}

Conclusion: However, sugarcane bugasse and crushed maize (Corcyra rearing waste) substrate were recorded no fungal spores. FYM was the best and suitable substrate for long time storage with viability of fungal spores.

\section{References}

1. Bharati, T., Kulkarni, J.H., Krishnara, P. U. and Alagawadi, A. R. (2007). Evaluation of Food Grains and Agro Wastes for Sporulation of Metarhizium anisopliae (Ma2). Karnataka Journal of Agricultural Science, 20(2): 424-425

2. Derakshan, Ali, Rabindra, R.J., Ramanujam, B. and Rahimi, M. (2008). Evaluation of different media and methods of cultivation on the production and viability of entomopathogenic fungi, Verticillium lecanii (Zimm.) Viagas. Pakistan Journal of Biological Science, 14

3. Hall, R.A. (1982). Deuteromycetes: Virulence and bioassay design, In: Invertebrate Pathology and Microbial Control. Proceedings of III International
Colloquium Invertebrate Pathology XV Annual Medium Society of Invertebrate Pathology, Brighton, U.K. pp.191-196.

4. Ibrahim, Y.B. and Low, W. (1993). Potential of Mass Production and Field Efficacy of Isolates of the Entomopathoghenic Fungi Beauveria bassiana and Paecilomyces fumosoroseus on Plutella xylostella. Journal of Invertebrate Pathology, 39: 222-232.

5. Lakshmi, S.M., Alagamai, P. and Jayaraj, S. (2001). Studies on mass culturing of the entomopathogenic white halo fungus, Verticillium lecanii on three grain media and its bioefficacy on Helicoverpa armigera (Hub.) on pigeon pea. In: Microbial in insect pest management, Ignacimuthu, S. and Sen, A. (Eds.). Oxford and IBH Publishing Co. Pvt. Ltd. New Delhi, pp: 111-115.

6. Moore, D., Lord, J. C. and Smith, S.M. (2000). Pathogens, In: B. Subramanyam and D.W. Hagstrum (Eds.), Alternatives to pesticides in stored-product IPM. Kluwer Academic Publishers, Boston, MA. Pp. 193-225. 
7. Nadeau, M.P., Dunphy, G.B. and Boisvert, J.L. (1996). Development of Erynia conica (Zygomycetes: Entomophtorates) on the cuticle of the adult black flies Simulium rostratum and Simulium decorum (Diptera: Simulidae). Journal of Invertebrate Pathology, 68: 5058

8. Nelson, L.T., Low, L and Glore, T.R. (1996). Large scale production of New Zeeland strains of Beauveria and Metarhizium, In: proceeding of the 49th the New Zeeland Plant Protection Conference. 49th the New Zeeland Plant
Protection Society Incorporated, pp: 257261

9. Pandey, A. K. and Kanaujia, K. R. (2008). Effect of different grains as solid substrate on sporulation, viability and pathogenicity of Metarhizium anisopliae (Metschnikoff) Sorokin. Journal of Biological Control, 22(2): 369-374.

10. Sharma, S., Gupta, R. B. L. and Yadava, C. P. S. (2002). Selection of a suitable medium for mass multiplication of Entomofungal pathogens. Indian Journal of Entomology, 64(3): 254-261. 